European journal of American studies

\title{
Resisting the Inevitable: Tar Sands, Regionalism and Rhetoric
}

Steven M. Hoffman, Paul Lorah and Joseph Janochoski

\section{(2) OpenEdition \\ Journals}

Electronic version

URL: https://journals.openedition.org/ejas/10372

DOI: $10.4000 /$ ejas. 10372

ISSN: 1991-9336

Publisher

European Association for American Studies

\section{Electronic reference}

Steven M. Hoffman, Paul Lorah and Joseph Janochoski, "Resisting the Inevitable: Tar Sands,

Regionalism and Rhetoric", European journal of American studies [Online], 9-3 | 2014, document 2,

Online since 23 December 2014, connection on 08 July 2021. URL: http://journals.openedition.org/ ejas/10372 ; DOI: https://doi.org/10.4000/ejas.10372

This text was automatically generated on 8 July 2021 .

Creative Commons License 


\title{
Resisting the Inevitable: Tar Sands, Regionalism and Rhetoric
}

\author{
Steven M. Hoffman, Paul Lorah and Joseph Janochoski
}

\section{Introduction}

1 Tar sands oil is rapidly becoming a primary means of powering the world's petroleumbased economy. Its development is being positioned as a vital component of North American continental energy security and is increasingly a vector of transboundary cooperation and contention. While some of the infrastructure necessary for the full development of the resource is already in place, significant additional investments capable of linking a complex and expanding system of oil fields, pipelines, refineries, and marine terminals will be required in the near term. The components are or will be located in a vast region extending from Alberta, Canada to the Gulf Cost of the United States to new consumer bases in Europe and Asia.

Despite a number of formidable barriers, an oppositional momentum is developing that involves a disparate set of local, national, and international actors. Many of these voices, most notably the First Nations of Canada and the United States as well as environmental activists on both sides of the border, have either been historically marginalized, or more recently, castigated as treasonous by the Canadian government (see Harper; Oliver). This paper discusses the diverse nature of this opposition through an examination of 26 collective activities involving 243 organizations that occurred between April, 2013 and February, 2014 (see Appendix A). The activities were identified by the authors from e-mails and related sources received through membership in a restricted electronic distribution list. The issues addressed by the network, the types of activities in which they are engaged, and the types of organizations driving the network are described below.

3 The first part of the paper discusses the internal characteristics and the network dynamics of these activities; this is followed by a geographically-defined analysis of the relationships among the participant organizations. The final section of the paper 
suggests that an important mechanism for achieving collaborative integrity in the midst of what are oftentimes very challenging circumstances are carefully elaborated rhetorical frames designed to appeal to a diverse set of key stakeholders and policymakers.

\section{Tar Sands and the Oppositional Field}

4 The rapid development of Canadian tar sands has spawned vigorous oppositional activity defined, in large part, by the nature of the development process itself. While the resource is located primarily in the province of Alberta, Canada, the infrastructure required to fully exploit this resource spans the North American continent. The system begins with massive 'plays' or oil deposits, estimated to be the size of the American state of Florida, that are located primarily in northern Alberta. After removal, either through surface mining or through an underground process known as in situ extraction, the oil is transported through a spider web of pipelines and rail connections that begin in Alberta and radiate outward to all parts of both the United States and Canada (Valentine).i These pipelines and rail carscarry either refined tar sands crude known as syncrude or dilbit, a particularly dangerous form of unrefined crude oil (Swift, Casey-Lefkowitz, and Shope), to refineries and ports at sites ranging from the coast of British Columbia and the Gulf of Mexico to the American side of the Great Lakes and the east coast of the United States. From there, tar sand-based products are shipped throughout North America, Asia, and Europe (Oil Change International).

When completed, the extraction sites, pipelines, refineries, and ports will constitute an integrated energy system. This system, however, is being assembled in a highly fragmented and incremental fashion useful for minimizing both regulatory oversight and oppositional resistance. In the case of regulation, oversight involves numerous federal, state, tribal, and local jurisdictions in Canada and the United States, whose authority varies depending upon the specific issue in question (Spruyt; Muldoon, Lucas, Gibson, and Pickfield). In the United States, for instance, primary regulatory responsibility for pipelines rests with national authorities while refinery developments are more heavily influenced by state regulators, even if they involve the acquisition of federal permits or the meeting of federal environmental standards (Association of Pipelines). For a variety of reasons, this fragmented regulatory environment is of great benefit to industrial and commercial interests, including the fact that no single regulatory authority is responsible for assessing system-wide impacts (Hoffman, "Many Pieces").

6 The nature of the development process is also reflected in the collective activities considered in this analysis. Thus, the issues addressed, the types of activities, and the types of organizations involved in oppositional work all exhibited a significant degree of diversity and variation. While the Keystone XL pipeline was prominent amongst the list of concerns, for instance, other issues included the climate-changing emissions enabled by tar sands development (Lattanzio; Brandt), generic concerns with both pipeline and rail safety, and conflict of interest claims in regards to various environmental review processes. Other activities were organized around issues of specific local concern, such as the perceived violations of property rights along various pipeline corridors or environmental justice claims associated with health impacts on communities located within the shadow of one or more mines. 
7 The types of collective activities undertaken by oppositional actors were also symptomatic of the development process. For instance, rather than directing their efforts towards one public authority, or even different public authorities in one country, organizers adopted a thematically differentiated and geographically wideranging set of tactics and strategies. Letters of concern were sent to a variety of public officials, including the President of the United States and the American Secretary of State, as well as national, state, and provincial agency officials, including Alberta's chief energy regulator. Jointly-authored and/or co-sponsored reports on issues both generic and local (NRDC), collaboratively-authored testimony submitted in response to a diverse set of regulatory proceedings, and the organization of multi-site rallies in both the United States and Canada all reflected the fragmented character of the development process.

8 Finally, the diffuse nature of the existing and potential harms caused by the exploitation of tar sands stimulated participation by a diverse set of organizations. Participants included very local, and often times minimally financed, citizen-based and/or all-volunteer organizations such as the Sebago Lake Anglers Association as well as regional or state-based groups such as the Minnesota Center for Environmental Advocacy, the Michigan Land Use Institute, Maine Rivers and the Environmental Advocates of New York. National, well-endowed legacy organizations such as the Natural Resources Defense Council and the National Audubon Society were also active players, in many cases being responsible for soliciting participation on the part of small and locally-oriented organizations. The nature of participation by these national organizations depended, in part, upon their particular organizational structure. The Sierra Club, for instance, is a 'federated' organization with both a central office and many local, and to some extent autonomous, local chapters. In some instances, the national office was deeply involved in a specific issue while in other cases, one or more local chapters participated in an activity without the participation of the national office.

9 Another important feature of the evolving tar sands oppositional network was the use of coalitional structures. In some cases, such as Pipe Up Against Enbridge and Bold Nebraska, these coalitions possess institutional characteristics such as an independent board of directors, a regularly published newsletter, or an actual physical location. In other cases, however, the coalition was intentionally temporary, with participants coming together only long enough to complete a particular action and having no intention of finding a way to sustain itself in any formal manner.

Given the diversity of the participating organizations, it is not surprising that the motivations inspiring participation were also very diverse. In some cases, it was a longheld affinity to a particular issue or normative concern that prompted action. Thus, a number of First Nation or American Indian organizations signed on to a letter objecting to the expansion of Shell Oil's Jackpine facility out of a general concern with aboriginal issues rather than because of any particular interest in tar sands. Other such affinities included property rights, environmental justice, or the degradation of very particular local landscapes such as the sand dunes of Lake Michigan or the possible spoilage of Nebraska's Ogalalla aquifer.

11 Another important feature of the network was the extent of participation amongst organizations. In many cases, participation was a one-off experience, with many of the individual activities being populated by numerous 'single-issue joiners' whose 
participation was occasioned by a specific interest or a localized impact of the sort discussed above. Indeed, of the 243 organizations identified in the analysis, some 142 (58 percent) participated in just one of the 26 collective activities (Table 1 ). In many cases, such organizations constituted a very high proportion of the total numbers of participants in any particular activity (Appendix B).

\begin{tabular}{|l|l|}
\hline $\begin{array}{l}\text { Table } 1 \\
\text { Number of Collective Activities }\end{array}$ \\
\hline Number of Activities & Number of Organizations Participating in Number of Activities \\
\hline 1 & 142 \\
\hline 2 & 45 \\
\hline 3 & 14 \\
\hline 4 & 13 \\
\hline 5 & 9 \\
\hline 6 & 6 \\
\hline 7 & 4 \\
\hline \hline 12 & 2 \\
\hline \hline 15 & 1 \\
\hline \hline
\end{tabular}

12 In contrast to these single-issue joiners was a small subset of actors standing at the center of collaborative activity. Unlike the more than 75 percent of organizations participating in either one or two of the activities, eight organizations ${ }^{\text {ii }}$ participated eleven or more times, oftentimes with a number of other dominant organizations (Table 2). In fact, almost 20 percent of the 561 connections generated by the 26 collective activities were the product of the interactions amongst the top eight joiners.

\section{Table 2}

Top Eight Joiners Interactions 


\begin{tabular}{|l|l|l|l|l|l|l|l|l|}
\hline Organization & $\mathbf{3 5 0 . 0 r g}$ & Bold NE & CBD & FOE & NRDC & NWF & OCI & Sierra \\
\hline 350.org & $\mathrm{xx}$ & 10 & 8 & 10 & 12 & 12 & 9 & 11 \\
\hline Bold NE & 10 & $\mathrm{xx}$ & 9 & 11 & 11 & 8 & 11 & 11 \\
\hline \hline CBD & 8 & 9 & $\mathrm{xx}$ & 8 & 10 & 6 & 9 & 9 \\
\hline \hline FOE & 10 & 11 & 8 & $\mathrm{Xx}$ & 10 & 7 & 10 & 9 \\
\hline \hline NRDC & 12 & 11 & 10 & 10 & $\mathrm{xx}$ & 10 & 11 & 13 \\
\hline \hline NWF & 12 & 8 & 6 & 7 & 10 & $\mathrm{xx}$ & 7 & 9 \\
\hline \hline OCI & 9 & 11 & 9 & 10 & 11 & 7 & $\mathrm{xx}$ & 10 \\
\hline \hline Sierra & 11 & 11 & 9 & 9 & 13 & 9 & 10 & $\mathrm{xx}$ \\
\hline
\end{tabular}

13 The different sorts of participatory experiences are illustrated in Fig. 1. On the left side of this figure is a small slice of the overall network, one that highlights the tendency of many organizations to limit their participation to one or perhaps two activities. The right side of Fig. 1, on the other hand, illustrates the highest level of network density, a center that is rich with multiple intersecting and overlapping interactions. 
Figure 1: Elements of Total Network

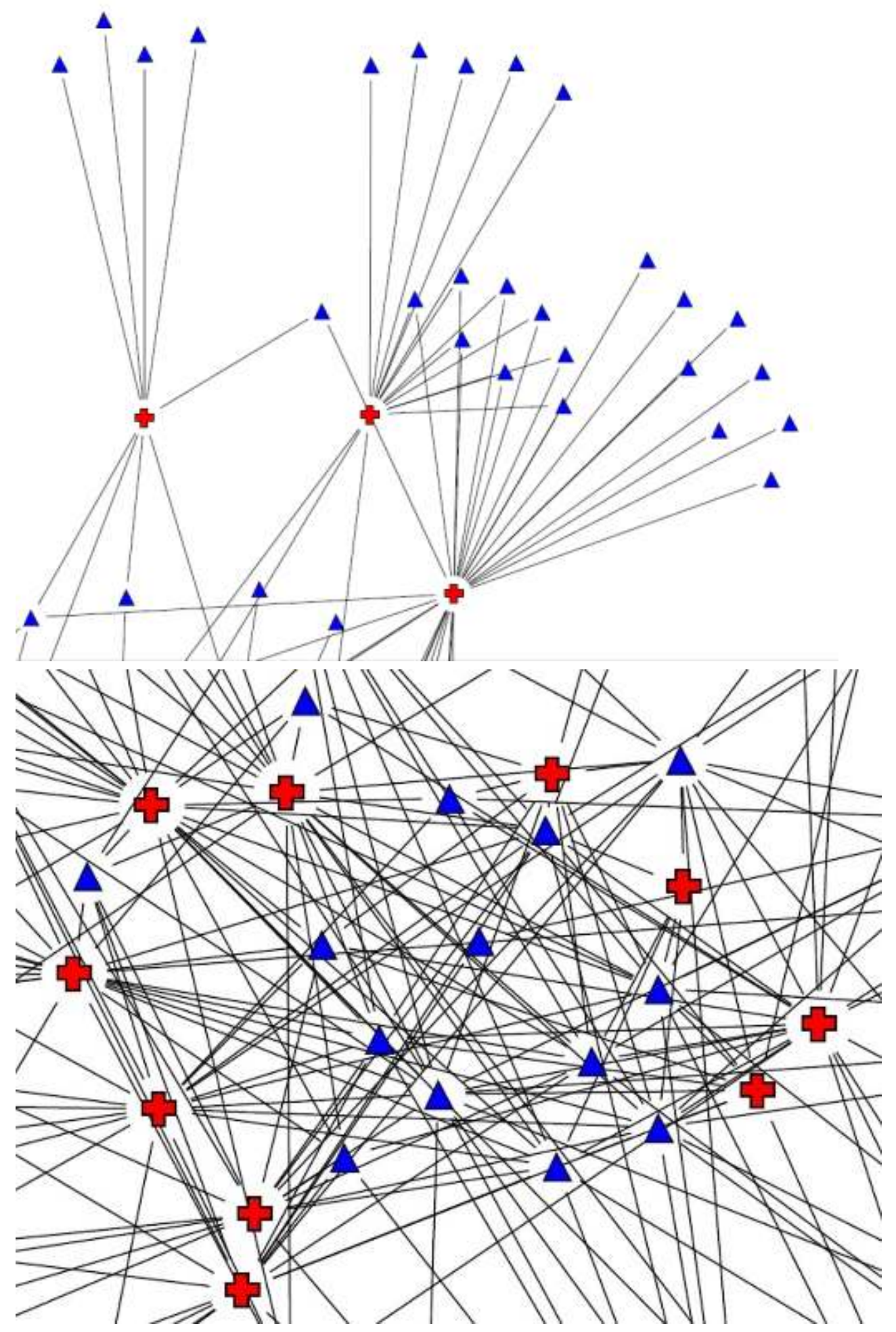

Crosses indicate activities; Triangles indicate organizations

14 The 'bi-polar' nature of this oppositional field, i.e., repeated interactions amongst the same large, national partners combined with a host of occasional or single-issue participants, presents both challenges and opportunities for future collaborative activity. On the one hand, repeated collaboration amongst the same large, national 
actors can easily precipitate the creation of a subsystem resistant to external influence (Lowi). Policy-making officials can also become immune to the entreaties offered by these actors, seeing them as 'the usual suspects' that are either safe to ignore or that can be placated by relatively modest actions on the part of the state or industry.

However, by creating linkages that would have otherwise been left unexploited and identifying a broad and diverse set of partners, dominant actors in an emerging network can lay a strong foundation for future network expansion. 350.org, for instance, through its involvement in 17 of the 26 activities, worked with some 170 organizations, 109 of which were single-issue joiners, any or all of which might be called upon by 350.org to renew their collaboration at some point in the future. While the other dominant organizations were not quite so energetically involved with singleissue joiners, they all nonetheless allied themselves with many organizations that would have otherwise remained unconnected to the overall oppositional effort.

The diversity of oppositional actors sprinkled throughout the full set of activities also meant that a host of potentially significant 'bonding' opportunities were created. Single-issue joiners, for instance, while standing at the periphery of the web of relations created by the various activities, nonetheless have clear pathways potentially connecting them with all of the other network participants, including a great number of organizations with very different ethnic, socio-economic, or political characteristics (Woolcock 197-212). The Vegans and Vegetarians of Alberta, for instance, would be unlikely to think of partnering with an organization such as Sand Hills Beef. Yet, both were at least indirectly allied by virtue of their work with the Indigenous Environmental Network (IEN) through their common participation in activities $\mathrm{C} 4$ and C5, respectively (Fig. 2). Even if, as noted above, these single-issue joiners do not participate in any of the other tar sands-related activities, such participatory experiences may well offer them future opportunities for collective action in areas wholly unrelated to tar sands. Indeed, this is one of the great opportunities afforded to even 'one-off' participants in a complex and evolving network, namely, unforeseen but potentially valuable opportunities for future interactions facilitated by the familiarization occasioned by even indirect collaboration organized around a common goal.iii 


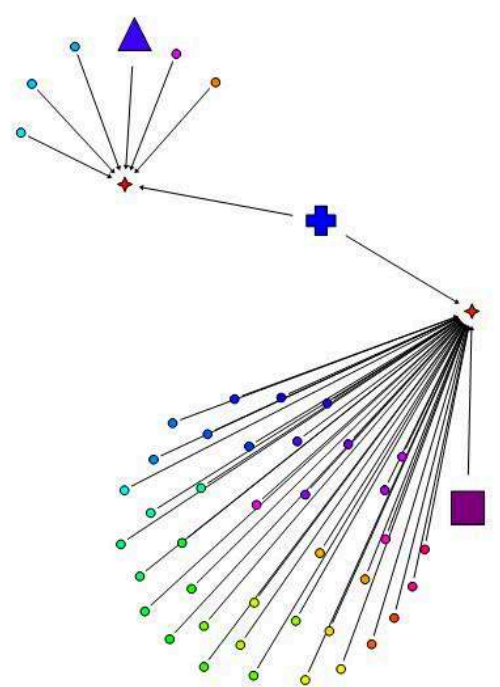

Triangle indicates Sand Hills Beef; cross indicates IEN; square indicates V/V of Alberta; left star indicates C4; right star indicates C5; circles indicate other participants

In addition to such bonding opportunities, more substantive bridging or linking ties were also created. Relations of this sort, that is, "between different social strata in a hierarchy where different groups access power, social status and wealth" (Voyer 31), are based on voluntary associational behaviors that connect individuals or the community with individuals or institutions that "hold different positions in a system of social hierarchy" (Iosifides, Lavrentiadou, Petracou, and Kontis 1345). Interactions amongst such diversely advantaged partners may well confer benefits to an organization no matter their location in the hierarchy. Small, local organizations with limited capacity, for instance, might acquire resources necessary to carry out their work while large, nationally prominent organizations can extend the range of their own actions by partnering with local entities, especially in the case of a project identified as having a well-understood local footprint. In agreeing to be listed as a contributing partner on a highly publicized Trailbreaker project report (NRDC), for instance, the Maine Clammers Association might well have increased their legitimacy as an oppositional organization while at the same time offering NRDC a pathway into a constituency that might have previously viewed such a prominent liberal environmental organization with some suspicion.

\section{Space Matters: The Geography of Tar Sands Oppositional Activity}

18 The fragmented nature of the tar sands development process is also deeply reflected in the spatial dimensions of collective activity. As Diani points out, networks "do not develop in a vacuum but are embedded in specific territories" (229). While intergroup interaction facilitated by electronic communication and social media may have 
lessened the need for in-person meetings and thus proximate location, there is no doubt that space matters and that a number of critical geographic dimensions, including very regionally-specific patterns of interaction, continue to be defined by the U.S.-Canadian border.

The geographic nature of the collaborative process can be illustrated in two ways, the first being standard deviational ellipses that were calculated for each coalition using the location of participating organizations. ${ }^{\text {iv }}$ Individual ellipses display the directional orientation of each coalition while also providing insight into the relative dispersion or clustering of member organizations, as coalitions of nearby organizations are represented by smaller ellipses than coalitions with dispersed membership. Fig. 3 displays ellipses for each of the 26 collaborative activities. Roughly half of the ellipses have a Canadian orientation, with most including organizations resident in both Toronto and Vancouver. Collaborative activities with an American orientation generally included the top eight joiners whose headquarters are on the east coast, primarily in Washington, D.C., or on the west coast. ${ }^{v}$ In both cases, the result are partnerships that are dominated by primarily U.S.- or Canadian-based organizations and ellipses that tend to demonstrate an east/west orientation.

Figure 3: Standard Deviational Ellipses

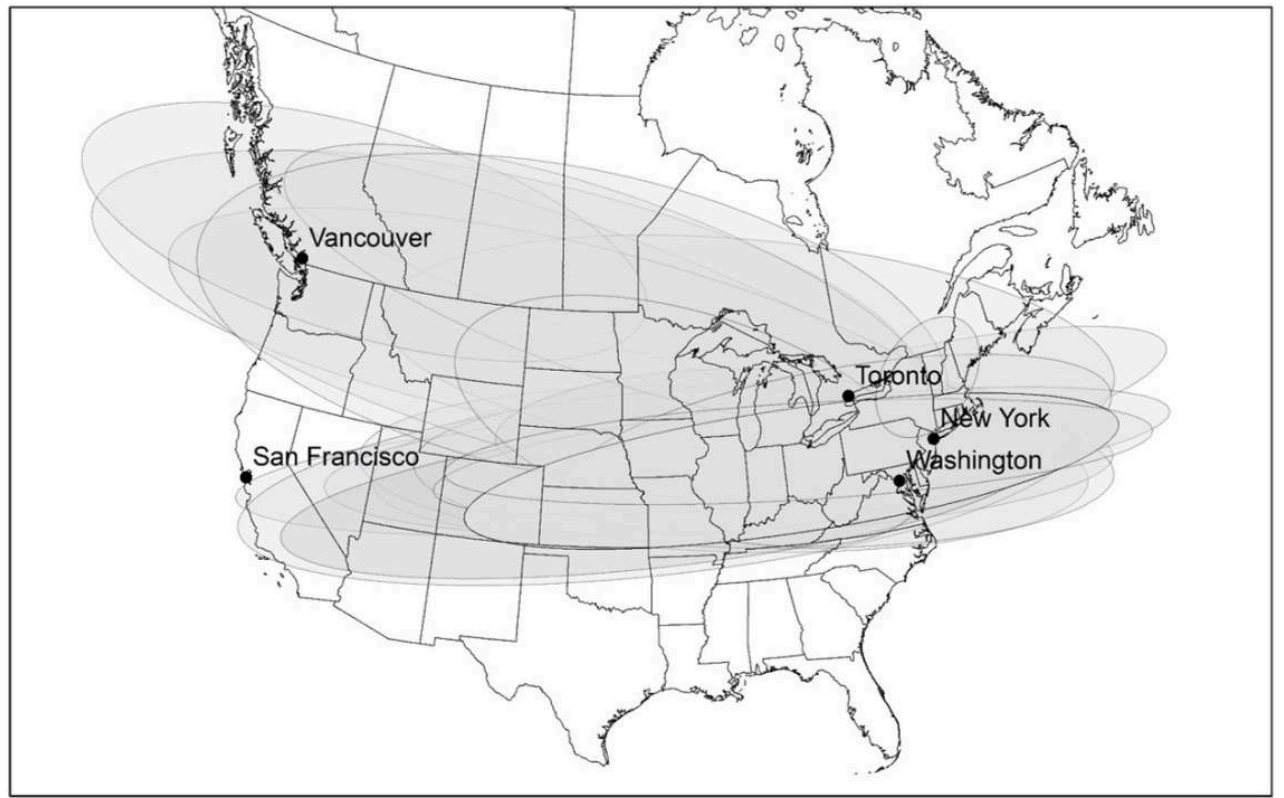

The bias towards finding partners in one's home country is particularly pronounced for single-issue joiners. Indeed, for a significant number of activities, all of the single-issue joiners were of U.S. origin and in all other cases the activities were dominated either by U.S. or Canadian organizations (Fig. 4). 

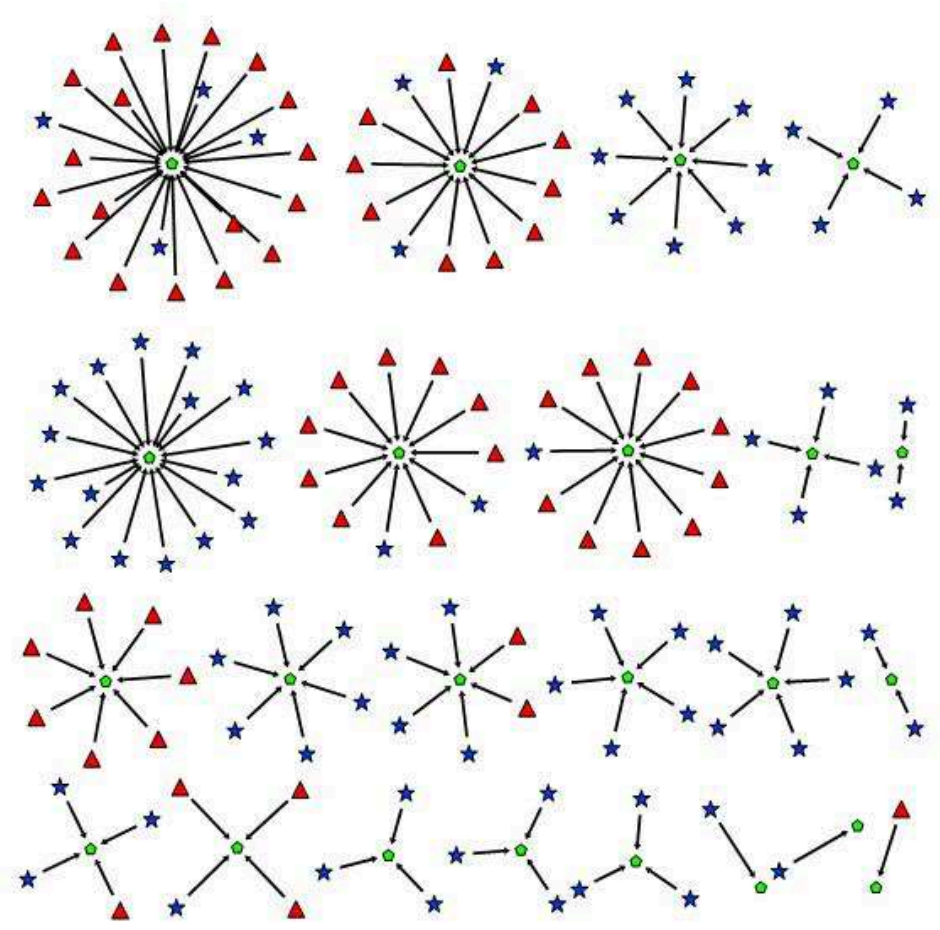

Star indicates U.S.-based organization; triangle indicates Canadian-based organizations; pentagon indicates collective activities; $\mathrm{C} 2, \mathrm{C} 13$, and $\mathrm{C} 18$ did not have any single-issue joiners

In addition to their alignment with partners of a similar national pedigree, organizations were in many cases clearly biased towards regional proximity in the construction of collective activities, a preference that again reflects the piecemeal and regional nature of the tar sands development process. The preference for proximity or dispersion is expressed by the 'nearest neighbor statistic' (NNS), a measure used by geographers to determine whether activities are spatially clustered or dispersed based on the average distance of each organization to its nearest neighbor. This statistic is calculated by measuring the distance between the location of each organization's office and that of its nearest neighbor. All of these nearest neighbor distances are then averaged and then divided by the expected distance of a hypothetical random distribution. If the average observed distance is less than that of a random distribution, organizations in the coalition are considered clustered, while an average distance greater than that of a hypothetical random distribution is considered dispersed (McGrew and Monroe). As can be seen in Table 3, while a number of activities demonstrated a relatively high degree of dispersion, the more common experience were activities that expressed a clear dependence upon regional neighbors, as indicated by relatively low NNS scores. Those activities that were widely dispersed were populated by a large number of the top eight joiners or by organizations with a strong affinity- or interest-driven bond that was independent of geographic location, such as a general interest in climate change. 
Table 3: Nearest Neighbor Statistic

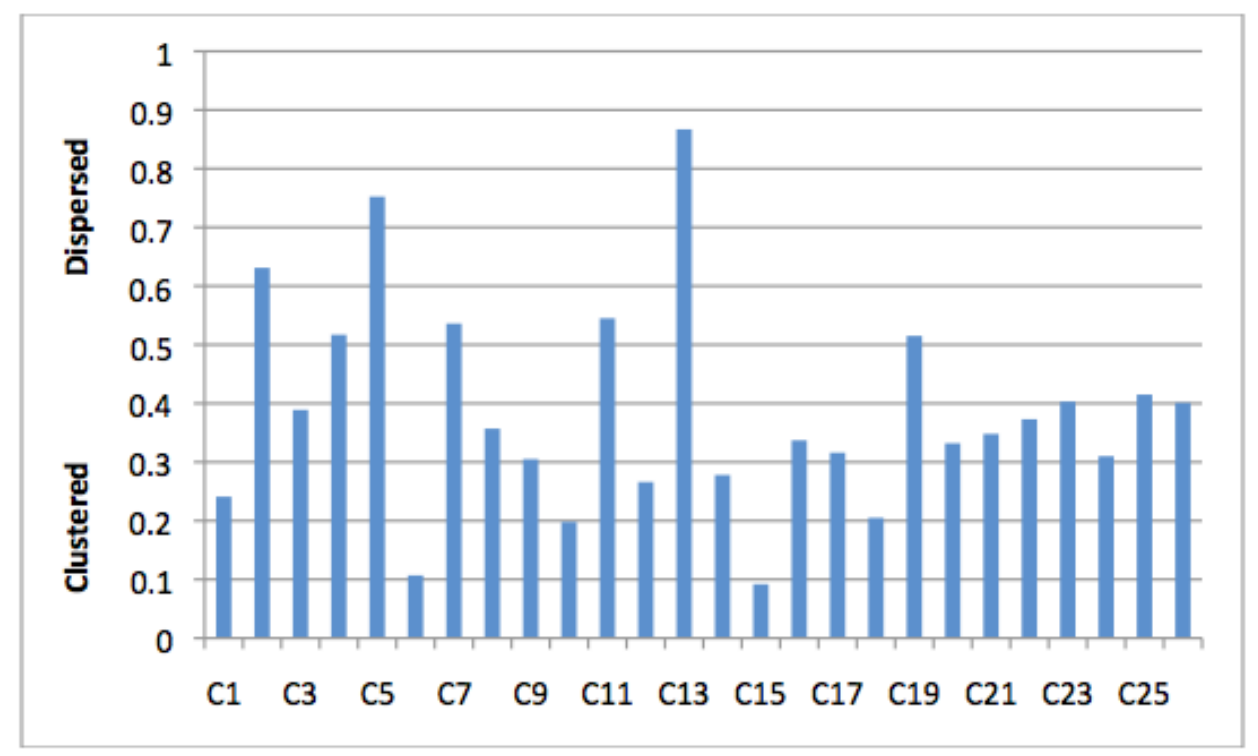

When considered in combination, the standard deviational ellipses and the NNS scores can yield significant insights into the geographical nature of collective activity. For instance, a geographically dispersed activity, or an ellipse that covers a broad swath of territory, combined with a relatively lower NNS indicates the presence of both geographically distant organizations and a set of clustered partners. Such is the case with the Jackpine expansion activity (C5), where a large number of Alberta and British Columbia-based organizations collaborated with a geographically dispersed set of organizations attracted by a general affinity with First Nations issues. On the other hand, an activity that draws upon widely dispersed organizations without a significant degree of clustering yields a relatively higher NNS score, due to the great distances between the participating organizations, and an ellipse that is again geographically extensive; the Keystone Climate Analysis (C13) is such an example. These compare with activities that feature both highly clustered organizations and the absence of geographically distant participants. In this case, the ellipse will be geographically limited and the NNS score will be small, characteristics demonstrated by both the Rally for the Great Lakes (C15) and the letter regarding the Pipeline \#9 (C6; Fig. 5). 
Figure 5: Standard Deviational Ellipses for Selected Activities

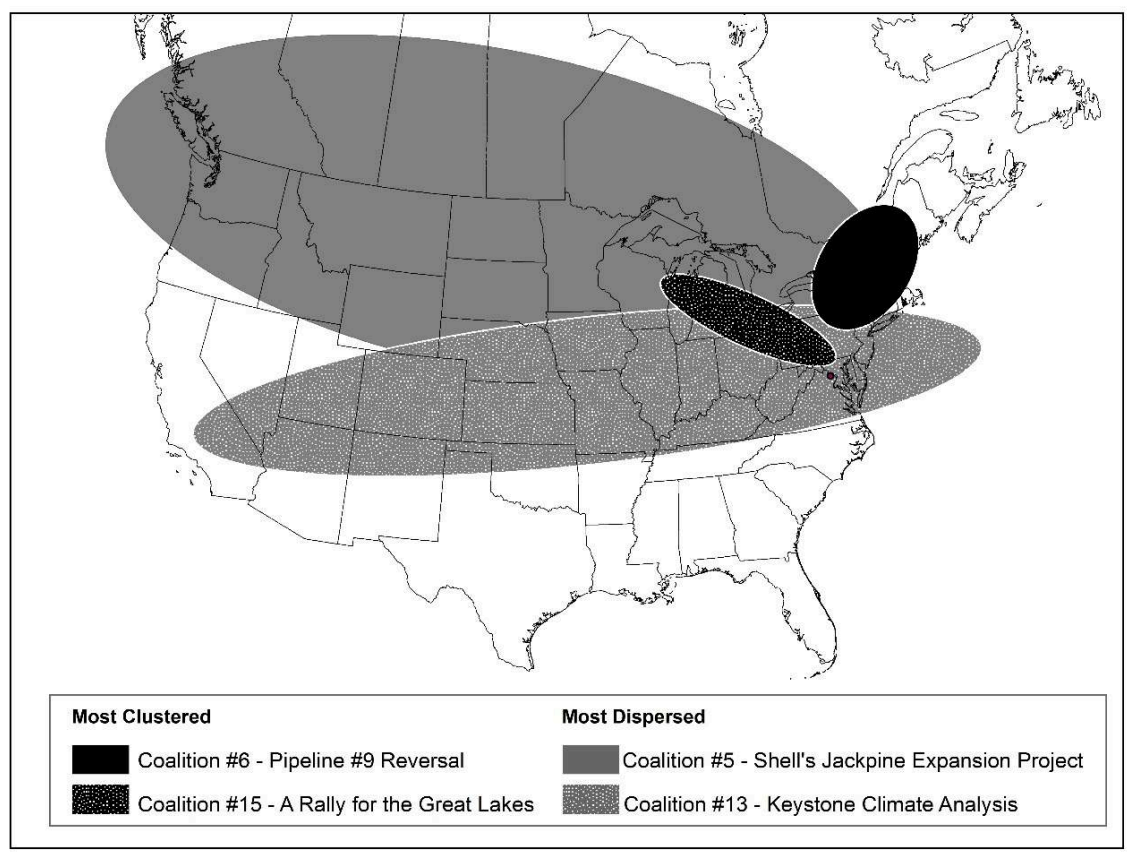

\section{Rhetoric: The Ties That Bind (Sometimes)}

The organizational interactions discussed to this point pose significant challenges to those hoping to build upon whatever successes have been achieved thus far. Even the most astute coalition-builder faces an array of difficulties, i.e., identifying and selecting suitable coalition partners, establishing the rules of interaction and cooperation, selecting the 'public voice' for the coalition, identifying the target(s) of a specific campaign, and so on. Given the extremely fragmented character of the tar sands development process, however, the most difficult challenge of all might well be the selection of a rhetorical or narrative frame, particularly one that as Croteau and Hicks say, can link "previously existing organizational frames in some complementary fashion" (253) and represent and communicate a variety of concerns to affected parties, the public at large, and decision makers. This is a particularly critical issue in a situation where geography and space matter and where, as shown above, many of the collective activities are populated by single-issue joiners in league with a subset of nationally-oriented organizations.

As noted by Snow and Benford, a frame is

the production and maintenance of meaning for constituents, antagonists, and bystanders or observers. This productive work may involve the amplification and extension of extant meanings, the transformation of old meanings, and the generation of new meanings.... [Framing] is the politics of signification (136).

In this regard, frames serve several functions, including as modes of punctuation, i.e., they encode certain events with meaning; attribution, i.e., they identify responsible agents and identify potential courses of remedial action; and signification, i.e., they take 
discreet events and weave them together into a consistent and unified narrative. Thus, a frame will shape how various parties (including activists), constituents (including members of an advocacy organization), decision makers, and the general public "define problems, attribute causes, and evaluate solutions" (Foust and Murphy 153).

Similar to the idea of a frame is that of a discursivenarrative or a "complex differentiated practice of representation that reflects the circulations and dispersions of power/knowledge in a particular historical moment," the development of which "permit[s] the activation of incompatible themes, or, again, the establishment of the same theme in different group statements" (Endres 924). Importantly, a discursive narrative is both "enabling and restraining" in that it "governs and opens the possibilities for resistance to discourse about a given topic" (924). In this sense, both a master frame and a dominant discursive narrative may well provide the sort of 'rallying point' around which an effective opposition might cohere. Conversely, both could inhibit the development of potentially useful competing narratives or thematic choices useful to that same oppositional community.

In some cases, particularly in the case of a well-defined and mature social movement, an especially compelling frame can become a "master frame" or an overarching sense of things into which the themes and frames employed by various organizations have to fit, at least to the extent that they care to be seen as part of 'the movement.' Examples of master frames are many and varied and include such examples as injustice frames, opposition frames, rights frames, and more specific frames such as the 'growth is good' frame, the 'environmental justice' frame, and the 'free market' frame (Benford 677-701).

In a collective activity composed of many diverse organizations, whether they are dispersed across an entire continent or are geographically proximate, constituent members must often spend an enormous amount of time and effort negotiating and constructing a "shared frame for the coalition as a whole" (Dahmus 17). Central to this process is the selection of a set of verbal images that can be paired with arresting visual images (DeLuca), i.e., 'tag lines' or short, easily recalled phrases, stories, or other narrative forms..$^{\mathrm{vi}}$ In the case of tar sands, the fragmented nature of the development process and the need to construct an oppositional environment around a plethora of particular circumstances greatly complicates the search for coherent, unifying and sustainable narrative frames.

\section{Case Study: A Call for New Pipeline Standards and Regulation}

In order to better understand the relationship between such a highly fragmented development process and the selection and use of an oppositional frame or discursive narratives, a collaboratively authored petition directed to the United States Department of Transportation, Pipeline Hazardous Materials Safety Administration (PHMSA), and United States Environmental Protection was analyzed (Citizen Petition). The petition, which was submitted by counsel of the National Wildlife Federation along with attorneys from the Vermont Law School Environmental and Natural Resources Law Clinic and the Sierra Club, was signed by 29 organizations and several dozen individuals. The participating organizations also are representative of the broad range of local, regional, and national organizations that populate the oppositional 
environment discussed above (see Appendix C). While this petition is just one of many documents and statements that were available for analysis, given the number of participating organizations and its broad geographic scope, the petition is a particularly useful demonstration of the non-spatial, spatial and rhetorical dynamics confronting the emerging tar sands oppositional network.

30 A number of questions were addressed in the analysis of the petition, including whether there exists a distinct or consistent coalitional rhetorical theme, one "that links previously existing organizational frames in some complementary fashion" (Croteau and Hicks 253); to what extent the constituent organizations use different and/or locally-oriented themes, messages, or rhetorics that reflect local issues, landscapes features, or culturally-specific factors; and even if the coalition partners use apparently similar rhetoric, does the underlying meaning of the rhetoric diverge in ways understood by the target groups unique to each coalition partner.

The first of these questions concerns the rhetorical or narrative language used by the coalition as a whole. As is typical of the activities considered in this paper, the material routinely generated by an organization through which a rhetorical frame might be identified, i.e., meeting minutes, resolutions, or various communication vehicles, was not available for analysis. Instead, it is assumed that the petition itself was the mechanism through which a collective frame was derived and that participating members codified the choice of frame by agreeing to be listed as a co-signer to the petition. Should a member have strongly disagreed with either the substance of the petition or the framing rhetoric it is assumed that they would have not have signed the petition.

32 An analysis of the petition reveals an abundance of rhetorical frames that might resonate with cooperating organizations in the formation of what Croteau and Hicks refer to as a "consonant frame pyramid" that integrates "the organizational frames developed by coalition members with the coalition's own frame" (253). For instance, the petition made numerous references to potentially significant harmful impacts on the health of the environment and the public, a theme taken up by many local participants. The petition referred to "vast areas of lush boreal forest that must be mined in order to extract tar sands, or large underground injection wells must essentially cook the tar sands using massive quantities of hot steam to melt the bitumen so it can be brought to surface" (16) and that "utilizing tar sands oil results in much greater greenhouse gas emissions and climate impacts than conventional crude oil" (39). The petition also asserted that "there is increasing evidence that the transport of diluted bitumen is putting America's public safety at level of risks much more acute than are seen in spills of conventional crude" $(17,18)$. As a result, "the rapid expansion of diluted bitumen infrastructure in existing or proposed pipelines impacts significant portions of the United States, endangers countless communities, and threatens some of our most vital resources" and "numerous ecologically important natural resources from the Great Lakes to the Ogallala Aquifer to Casco Bay as well as countless communities and citizens" (18). Indeed, says the petition, "as tragic and costly as the Kalamazoo spill was and continues to be, a spill in a resource such as the Straights of Mackinaw-which is currently exposed to diluted bitumen risks-would be immeasurably higher" (47).

The importance of the geographical spaces noted above was paralleled by the rhetorical space used by many of the participating organization as they took up these themes 
while utilizing distinctive, localized references. ${ }^{\text {vii }}$ New Hampshire Audubon, for instance, argued that tar sands is the "dirtiest oil on planet," a language also used by the Western Organization of Resource Councils who claimed that "TransCanada, a Canadian company, wants to build a 36-inch pipeline to carry up to 37.8 million gallons daily of dirty tar sands oil from Alberta, Canada through Montana, South Dakota, Nebraska and on to the Texas Gulf Coast." Save the Dunes, an Indiana-based organization claimed that a new pipeline "if built, could triple the amount of toxic tar sands oil moving through our region." An even more local connection was drawn by Environment Maine in their messaging:

ExxonMobil and Canadian oil giant Enbridge want to use an antiquated oil pipeline that passes right next to Sebago Lake to transport highly corrosive tar sands oil from Canada to Casco Bay for export. A tar sands spill in the Sebago watershed, or near any of Maine's waterways, would be utterly disastrous.... Sebago Lake is a Maine treasure-we escape there on hot summer days, we drink its water, and we watch our kids grow up on its shores.

The theme was echoed by New Hampshire Audubon when they pointed out that "this pipeline crosses 79 rivers and streams in New Hampshire.... A tar sands spill could permanently ruin some of the best trout streams in Coos County." The Vermont Natural Resources Council posited a similar degree of harm, telling its members that the Council

has been working hard to stop a shortsighted and dangerous plan to transport the world's dirtiest oil across Vermont's lovely Northeast Kingdom and beyond.... It would be all risk and little to no reward, with potential catastrophic consequences for Vermont's natural resources-the very backbone of the Northeast Kingdom's rural economy.

The Michigan Student Sustainability Coalition also pointed to a deadly combination of local and planetary harm with their assertion that "our nation, world, and climate face serious threats from the TransCanada Keystone XL Pipeline and Enbridge's planned international pipelines through the Great Lakes." Save the Dunes claimed that a proposed tar sands-linked pipeline in their area "crosses 60 miles of Northwest Indiana through Lake, Porter, LaPorte, and St. Joseph Counties"while the Western Organization of Resource Councils argued that "TransCanada, a Canadian company, wants to build a 36-inch pipeline to carry up to 37.8 million gallons daily of dirty tar sands oil from Alberta, Canada through Montana, South Dakota, Nebraska and on to the Texas Gulf Coast." viii

Another 'consonant narrative' was a basic mistrust of the part of oil industry brought on by its fundamental lack of integrity. In order to construct this narrative, the petition combined a deeply impersonal rhetoric, i.e., "oil giant Imperial Oil" (33), with specific actions on the part of industry leaders. Thus, the petition pointed out that "at the time of the Kalamazoo spill, Enbridge's CEO denied that the pipeline was carrying tar sands oil. As investigations began to reveal that the substance was indeed tar sands, the CEO finally admitted that the leak was tar sands oil" (32). Third party evidence, including that offered by authoritative governmental institutions, was also used to legitimate the underlying claim of unethical behavior. For instance, the petition said that "in evaluating the Kalamazoo spill, the NTSB [National Transportation Safety Board] was highly critical of this discretion afforded pipeline operators. NTSB concluded that largely as a result of past regulatory changes made at the urging of the American Petroleum Institute" the requirements for reporting spills is ambiguous, a situation 
that favors the industry (45). At the same time, the "PHMSA [the Department of Transportation's Pipeline Hazardous Materials Safety Administration] allows operators ample discretion to determine the adequacy of their own emergency plans with little checks to ensure those plans are indeed adequate" (49). Finally,

The process around approval [of emergency spill plans] is also critically lacking. There is no public review, no opportunity for input or comment, and PHMSA is horribly understaffed. For the Enbridge pipeline that spilled in Kalamazoo, the spill response plan was approved a mere two weeks after it was submitted. The plan was approved based on company submissions attesting to the adequacy of the plan. No supplemental information was sought in PHMSA's lightning-fast approval of the plan. (51)

These frames were combined with a narrative of risk and uncertainty in order to further undermine the believability and trustworthiness of the industry. The sense of uncertain, but no doubt very real, harm was heightened by the petition's assertion that "diluted bitumen further presents many troubling unknowns that complicate spill response" (34), including the fact that such "leaks in diluted bitumen pipelines are often more difficult to detect than leaks in pipelines carrying just conventional crude... [so] real leaks may go unnoticed" (38). The result is an environment where individuals face imminent danger, the reality of which was demonstrated in the "tragic" Kalamazoo spill where "toxic fumes forced local residents to flee from their homes and over 300 people suffered from immediate illness due to benzene exposure" (36).

A rhetoric of danger being unleashed by irresponsible, large, and inherently threatening corporate actors was also used by numerous coalition partners, again with references specific to the local space occupied by the various participants. Environment Maine, for instance, referred to the "Canadian oil giant Enbridge," a choice of words that coincided with New Hampshire Audubon's reference to "Enbridge, Canada's megaoil pipeline company." Environment Maine also referred to the company's plan to use "an antiquated oil pipeline that passes right next to Sebago Lake to transport highly corrosive tar sands oil from Canada to Casco Bay for export," a spill from which and into "Sebago watershed, or near any of Maine's waterways, would be utterly disastrous." "ix Michigan's Student Sustainability Coalition projected a similar degree of irresponsibility in its assertion that "our nation, world, and climate face serious threats from the TransCanada Keystone XL Pipeline and Enbridge's planned international pipelines through the Great Lakes."

While such rhetorical themes served to link "previously existing organizational frames in some complementary fashion" (Croteau and Hicks 253), the petition carefully avoided mentioning frames that could threaten the coherence of the coalitions' messaging by offending local sensibilities. For instance, many of the signees invoked the paramount significance of local control as an important means of protecting land and its associated environmental attributes, i.e., clean air and water, healthy forests, and so on. ${ }^{\mathrm{x}}$ The Conservation Law Foundation (New England) highlighted the fact that "at town meetings across the state earlier this month, 29 Vermont communities passed resolutions opposing the transportation and use of tar sands oil." The Midwest Environmental Advocates evinced a similar idea, arguing that "every citizen has the potential to make a difference," while the Northern Plains Resource Council (Montana) described itself as "a grassroots conservation and family agriculture group that organizes Montana citizens to protect our water quality, family farms and ranches, and unique quality of life." 

in the petition, perhaps because underneath this apparent agreement is a disagreement both fundamental and deeply felt, namely, a disagreement over the very thing that is to be protected and the vehicles that might be used in the course of its protection. On the one hand, Dakota Rural Action claimed that "South Dakota landowners have proven and earned their right to private property rights over multiple generations through their responsible stewardship" (emphasis added). The Nebraska Farmers Union also referenced threats to private property by calling attention to the "Nebraska Easement Action Team, a non-profit landowner rights group with the purpose of creating a standard and strong Nebraska easement designed to protect Nebraskans from all oil pipelines and oil pipeline companies." The Northern Plains Resource Council was even more explicit in its mission of helping landowners in the path of the pipeline to protect their land and water, as well as their legal rights. Thus, Northern Plains and their affiliates Dawson Resource Council and McCone Agricultural Protection Organization, created the Northern Plains Pipeline Landowners Group as a means of organizing landowners along the route to help them gain better information and negotiate from a stronger position, including hiring a lawyer to represent it in negotiations with TransCanada.

41 An emphasis on private property and landowners' rights contrasted sharply with a rhetoric of public lands used by many signees located in the Eastern part of the country. For these participants, the notion of public lands was a core frame that implies a number of fundamental values, including open access, responsibility to future generations independent of private ownership, and an ethic of "community decisionmaking to protect and restore local rivers, lakes and wetlands" (Freshwater Future). Thus, for Environment Maine, the primary danger of a tar sands-bearing pipeline is the threat it poses to a long-treasured public asset, namely, Lake Sabago, a body of water that has been "a favorite place to swim, boat, and fish for generations of Mainers" and is a source of "clean drinking water to the Greater Portland Area." In much the same fashion, Indiana-based Save the Dunes concluded that it is the lack of appropriate safety measures and the general irresponsibility of pipeline operators that threatens the "health of our communities" and jointly shared waterways.

These varying perspectives were not simply disagreements over language; instead, as suggested by Snow and Benford regarding the attributive role of a framing narrative, they reflected both fundamentally different views of the problem and the remedies seen as appropriate to addressing it. A ruptured pipeline, for instance, was seen by members of Environment Maine as a threat to the right of the public to enjoy a recreational resource not only now but for many generations to come. Faced with the potential destruction of such lands, designating a proposed pipeline route as public land in order to restrict the private use of the land is a perfectly reasonable response. To constituents of Dakota Rural Action, however, the threat is largely related to a pipeline's potential to damage private property and a landowner's ability to use property as they see fit. In this case, appropriate remedies might include greater compensation to individual landowners or revising eminent domain laws such that property owners would have a much greater say in determining whether a pipeline will be allowed to pass through their land. 


\section{Conclusion} development of Canadian tar sands, space clearly matters. National boundaries still present a significant line of demarcation for organizational action, and the location of a particular piece of infrastructure often compels organizations to seek out partners that are in relatively close proximity. While large, national or international organizations may be crucial in facilitating and broadening the range of organizational participation, it is the residents of actual places who suffer the direct harms imposed by the development process and who define the limits of space pertinent to many collaborative activities.

Equally important is rhetorical space. In an oppositional field composed of widely divergent organizations, participants in a collective activity must have the ability to develop a variety of messages using a language that speaks to their members and the diversity of interests they represent. They must do so, of course, while maintaining an essential adherence to the larger themes or the overarching master narrative embedded in a particular collective activity as well as the rhetoric and viewpoints espoused by their partners. As demonstrated in the petition calling for new pipeline standards and regulations, such rhetorical maneuvering is a vital and necessary aspect of collective activity. Whether the challenges imposed by space, place, and language can be successfully addressed in the future will, no doubt, play a very large role in determining the viability of an oppositional network that is only now taking shape.

\section{BIBLIOGRAPHY}

Association of Pipelines. "Economic Regulation.” 16 April 2012. Web. <http://www.aopl.org/cms/ index.cfm?fa=view\&id=1038>.

Benford, Robert D. "Frame Disputes within the Nuclear Disarmament Movement." Social Forces 71.3 (1993): 677-701. Print.

Boston-Tar-Sands-Patriots. Web. <https://groups.google.com/forum/\#!forum/boston-tar-sandspatriots>.

Brandt, Adam R. "Upstream Greenhouse Gas (GHG) Emission from Canadian Oil Sands as a Feedstock for European Refineries." Department of Energy Resources Engineering, Stanford University. 18 January 2011. Web. <https://circabc.europa.eu/d/d/workspace/SpacesStore/ db806977-6418-44db-a464-20267139b34d/Brandt_Oil_Sands_GHGs_Final.pdf> .

Citizen Petition Before the United States Department of Transportation, Pipeline Hazardous Materials Safety Administration and United States Environmental Protection Agency (Citizen Petition). 26 March 2013. Submitted by James G. Murphy et al. on behalf of coalition of parties. Web. $<$ www.nrcm.org/bv.asp?blob=277>.

Conservation Law Foundation (New England). Web. <www.clf.org>.

European journal of American studies, 9-3 | 2014 
Croteau, David, and Lyndsi Hicks. "Coalition Framing and the Challenge of a Consonant Frame Pyramid: The Case of a Collaborative Response of Homelessness." Social Problems 50.2 (2003): 251-72. Print.

Dahmus, Maria. Finding Common Ground: Coalitions Among Unlikely Partners for Natural Resource Policy in Minnesota. Madison, WI: University of Wisconsin-Madison, 2011. Print.

Dakota Rural Action. Web. <www.dakotarural.org> .

DeLuca, Kevin Michael. Image Politics: The New Rhetoric of Environmental Activism. New York and London: Guilford, 1999. Print.

Diani, Mario. "Social Movements and Collective Action." The Sage Handbook of Social Network Analysis. Ed. John Scott and Peter J. Carrington. Thousand Oaks, CA: Sage, 2011. 223-35. Print.

Endres, Danielle. "From Wasteland to Waste Site: The Role of Discourse in Nuclear Power's Environmental Injustices." Local Environment 14.10 (2009): 917-37. Print.

Environment Maine. Web. <www.environmentmaine.org>.

Foust, Christina, and William O'Shannon Murphy. "Revealing and Reframing Apocalyptic Tragedy in Global Warming Discourse.” Environmental Communication 3.2 (2009): 151-67. Print.

Freshwater Future. Web. <www.freshwaterfuture.org>.

Harper, Tim. "For Conservatives, Contrary Positions Are Treasonous." The Star.com. 17 November 2011. Web. <http://www.thestar.com/news/canada/politics/article/1088755--tim-harper-forconservatives-contrary-positions-are-treasonous $>$.

Hoffman, Steven M. "Many Pieces, One System: Regulatory Fragmentation and the Political Economy of Tar Sands." Paper Presented at the Meetings of the Midwest Political Science Association (6 April 2014).

Hoffman, Steven M. "If the Rivers Ran South: Tar Sands and the State of the Canadian Nation." Mining North America. Ed. John McNeill and George Vrtis. Oakland: U of California-Berkeley P (forthcoming).

Iosifides, T., M. Lavrentiadou, E. Petracou, and A. Kontis. "Forms of Social Capital and the Incorporation of Albanian Immigrants in Greece." Journal of Ethnic and Migration Studies 33.8 (2007): 1343-61. Print.

Lattanzio, Richard K. "Canadian Oil Sands: Life-Cycle Assessments of Greenhouse Gas Emissions."Washington, D.C.: Congressional Research Service, 2012. Web. <http://www.fas.org/ sgp/crs/misc/R42537.pdf >.

Lowi, Theodore. The End of Liberalism. New York: Norton, 1979. Print.

McGrew, J. Chapman, and Charles B. Monroe. An Introduction to Statistical Problem Solving in Geography. $2^{\text {nd }}$ Edition. Long Grove, Illinois: Waveland, 2000. Print.

Michigan Student Sustainability Coalition. Web. <http://themssc.wix.com/themssc>.

Midwest Environmental Advocates. Web. <www.midwestadvocates.org>.

Muldoon, Paul, Alastair Lucas, Robert B. Gibson, and Peter Pickfield. Environmental Law and Policy in Canada. Toronto: Emond Montgomery, 2009. Print.

Natural Resources Defense Council (NRDC). "Going in Reverse: The Tar Sands Threat to Central Canada and New England.” Washington, D.C., 2012. Web. <http://www.nrdc.org/energy/files/ Going-in-Reverse-report.pdf>. 
Nebraska Farmers Union. Web. <www.nebraskafarmersunion.org>.

New Hampshire Audubon. Web. <www.nhaudubon.org>.

Northern Plains Resource Council (Montana). Web. <www.northernplains.org>.

Oil Change International. “Refinery Report.”Washington, D.C., 2014. Web. <http:// refineryreport.org>.

Oliver, Joe."An Open Letter from the Honourable Joe Oliver, Minister of Natural Resources, on Canada's Commitment to Diversify Our Energy Markets and the Need to Further Streamline the Regulatory Process in Order to Advance Canada's National Economic Interest." 9 January 2012. Web. <http://www.nrcan.gc.ca/media-room/news-release/2012/1/3520>.

Save the Dunes. Web. <www.savedunes.org>.

Smerecnik, Karl R., and Valerie R. Renegar. "Capitalist Agency: The Rhetoric of BP’s Helios Power Campaign.” Environmental Communication 4.2 (June 2010): 152-71. Print.

Snow, David A., and Robert D. Benford. "Master Frames and Cycles of Protest." Frontiers in Social Movement Theory. Ed. Aldon D. Morris and Carol McClurg Mueller.New Haven and London: Yale UP, 1992. 133-53. Print.

Spruyt, Hendrik. "Juggling the New Triad-Energy, Environment and Security: A Case Study of the Canadian Oil Sands."Center for International Peace and Security Studies, Université de Montréal and McGill University, 2010. Print.

Swift, Anthony, Susan Casey-Lefkowitz, and Elizabeth Shope. Tar Sands Pipelines Safety Risks. Washington, D.C.: National Resources Defense Council, 2011. Web. <http://www.nrdc.org/ energy/tarsandssafetyrisks.asp>.

Valentine, Kate. "While America Spars over Keystone XL, a Vast Network of Pipelines Is Quietly Being Approved.” Climate Progress. 20 March 2014. Web. <http://thinkprogress.org/clmate/ 2014/03/20/3254081/pipelines-you-havent-heard-of/>.

Vermont Natural Resources Council. Web. <www.vnrc.org>.

Voyer, J.-P. “Diversity without Divisiveness: A Role for Social Capital?” Canadian Diversity 2.1

(2003): 31-35. Print.

Western Organization of Resource Councils. Web. <www.worc.org>.

Woolcock, M. "Managing Risk, Shocks, and Opportunities in Developing Economies: The Role of Social Capital." Dimensions of Development. Ed. G. Ranis. New Haven: Yale Center for International and Area Studies, 2000. 197-212. Print.

\section{APPENDIXES}

\section{Appendix A}

\section{SUMMARY OF COLLECTIVE ACTIVITIES}

C1 10-day NoKXL comments sprint 
C2 Letter to Harold Geisel, Deputy Inspector General, Office of Inspector General, U.S. Department of State re selection of ERM for third-party contractor to evaluate Keystone DEIS

C3 Letter to U.S. House members re H.R. 3 sponsored by Representative Lee Terry exempting Keystone from environmental review

C4 The All Risk, No Reward Coalition

C5 Shell's Jackpine expansion project

C6 Pipeline \#9 reversal signees of letter to Canadian National Energy Board

C7 Contributing organizations to NRDC Report on Trailbreaker project

C8 National coalition on pipeline standards

C9 Gary Protti appointment as Alberta energy regulator

C10 NYC Rally

C11 Alberta Clipper scoping comments

C12 Pipe Up Against Enbridge

C13 Keystone Climate Analysis

C14 Tar Sands Solutions Network

C15 A Rally for the Great Lakes

C16 Letter re railroad safety standards

C17 Letter to Kerry re REM conflict of interest

C18 Letter to Alberta Energy Regulator re CNRL blowouts

C19 Draw the Line protest

C20 Letter to Obama-'No Deal Mr. President'

C21 Letter to Assistant Secretary Linick-Department of State re conflict of interest

C22 Defend Our Climate actions

C23 NRDC Report on Tar Sands Oil and the Northeast

C24 Letter to Secretary Kerry re Pipelines and joint environmental review

C25 Telepresser post-KXL EIS release

C26 Say No to KXL vigils

\section{Appendix B}

\section{COMPOSITION OF ACTIVITIES}

\begin{tabular}{|l|l|l|l|l|l|}
\hline Activity \# & $\begin{array}{l}\text { Total \# } \\
\text { of Groups }\end{array}$ & $\begin{array}{l}\text { \# of Single } \\
\text { Issue Joiners }\end{array}$ & $\begin{array}{l}\text { \% of Single } \\
\text { Issue Groups }\end{array}$ & \# of Top Eight Joiners & \% of Top Eight Joiners \\
\hline C1 & 19 & 3 & $15 \%$ & 7 & $37 \%$ \\
\hline
\end{tabular}




\begin{tabular}{|c|c|c|c|c|c|}
\hline C2 & 12 & 0 & $0 \%$ & 7 & $58 \%$ \\
\hline C3 & 21 & 1 & $4 \%$ & 7 & $33 \%$ \\
\hline $\mathrm{C} 4$ & 9 & 4 & $44 \%$ & 1 & $11 \%$ \\
\hline C5 & 48 & 15 & $31 \%$ & 4 & $8 \%$ \\
\hline C6 & 17 & 1 & $5 \%$ & 3 & $18 \%$ \\
\hline C7 & 19 & 6 & $31 \%$ & 4 & $21 \%$ \\
\hline $\mathrm{C} 8$ & 29 & 8 & $27 \%$ & 2 & $7 \%$ \\
\hline C9 & 35 & 11 & $31 \%$ & 0 & $0 \%$ \\
\hline $\mathrm{C} 10$ & 20 & 16 & $80 \%$ & 2 & $10 \%$ \\
\hline C11 & 15 & 5 & $33 \%$ & 2 & $13 \%$ \\
\hline $\mathrm{C} 12$ & 23 & 7 & $30 \%$ & 0 & $0 \%$ \\
\hline C13 & 6 & 0 & $0 \%$ & 6 & $100 \%$ \\
\hline C14 & 28 & 3 & $10 \%$ & 7 & $25 \%$ \\
\hline C15 & 11 & 6 & $54 \%$ & 2 & $18 \%$ \\
\hline C16 & 53 & 22 & $41 \%$ & 2 & $4 \%$ \\
\hline C17 & 26 & 3 & $11 \%$ & 6 & $23 \%$ \\
\hline C18 & 22 & 0 & $0 \%$ & 0 & $0 \%$ \\
\hline C19 & 17 & 4 & $23 \%$ & 6 & $35 \%$ \\
\hline C20 & 23 & 5 & $21 \%$ & 6 & $26 \%$ \\
\hline C21 & 22 & 2 & 9\% & 8 & $36 \%$ \\
\hline $\mathrm{C} 22$ & 32 & 12 & $37 \%$ & 1 & $3 \%$ \\
\hline $\mathrm{C} 23$ & 16 & 2 & $12 \%$ & 5 & $31 \%$ \\
\hline C24 & 15 & 4 & $26 \%$ & 8 & $53 \%$ \\
\hline C25 & 10 & 1 & $10 \%$ & 7 & $70 \%$ \\
\hline C26 & 17 & 3 & $17 \%$ & 7 & $41 \%$ \\
\hline
\end{tabular}




\section{Appendix C}

\section{CASE STUDY}

Action:

Citizen Petition Before the United States Department of Transportation, Pipeline Hazardous Materials Safety Administration and the United States Environmental Protection Agency.

Participating Organizations:

Appalachian Mountain Club

Bold Nebraska

Conservation Law Foundation

Dakota Resource Council

Dakota Rural Action

Environment Maine

Freshwater Future

Fresh Energy

Great Lakes Environmental Law Center

Indigenous Environmental Network

Michigan Student Sustainability Coalition

Midwest Environmental Advocates

Minnesota Conservation Federation

Minnesota Center for Environmental Advocacy

National Wildlife Federation

Natural Resources Council of Maine

Nebraska Farmers Union

Nebraska Wildlife Federation

New Hampshire Audubon

New Hampshire Trout Unlimited

New Hampshire Wildlife Federation

Northern Plains Resource Council

Save the Dunes

Sebago Lake Anglers Association

Sierra 


\section{NOTES}

i. There are a number of additional pipelines currently in the planning stages, including Keystone XL, Northern Gateway, Energy East and a variety of related systems. Given the opposition facing many of these proposals, an increasing volume of oil is being transported by rail (see Hoffman, "If the Rivers").

ii. These organizations were 350.org, Sierra Club, Natural Resources Defense Council (NRDC), Bold Nebraska (Bold NE), National Wildlife Federation (NWF), Oil Change international (OCI), Center for Biological Diversity (CBD), and Friends of the Earth (FoE).

iii. Whether or not such interactions actually occur is fertile ground for future research that would involve a careful analysis of the sequence of participation and the extent to which subsequent participation was determined by prior experiences.

iv. Each standard deviational ellipse contains approximately 68 percent of the organizations in each collaborative activity. Three UK-based organizations participated in two of the activities. These were excluded for the analysis, given the geographic bias that would have been introduced into the calculation of the ellipses.

v. The exceptions are Bold Nebraska and the Center for Biological Diversity, which has its headquarters in Tucson, Arizona.

vi. BP's Helios Power Campaign, for instance, crafted a host of commercials and websites laden with visual and verbal cues such as "green," "clean," "conserve energy," "reduce waste," "save the world," "the environment," and "eco-friendly" designed to align with the target community's preexisting beliefs, including a desire to maintain a certain 'way of life' defined by consumerism and material satisfaction. Throughout what was by all accounts a very successful campaign, BP sought to convince consumers that small, incremental, and essentially painless actions, or what Smerecnik and Renegar call "capitalistic agency," were all that were required of a good environmental citizen.

vii. All of the quotations below come from the websites of the various organizations listed in the Works Cited.

viii. In many other cases, even when there is no explicit mention of the toxic character of tar sands crude, by referencing the organization's overarching concern with human health and safety and the protection of air and water, there is an implicit link between tar sands and the inevitable degradation of human health and air and water quality.

ix. The fact that the oil is for export and hence would benefit a foreign company and consumers outside of the locality only compounds the sense of harm without any corresponding benefit.

x. References to local political culture are found throughout the tar sands oppositional community. For instance, the 350.org affiliate Boston-Tar-Sands-Patriots uses a rhetoric that evokes the deepest form of regional identity when they describe themselves as a "group of patriots in the Boston area working together to fight the Keystone XL Pipeline."

\section{ABSTRACTS}

Tar sands oil is rapidly becoming a primary means of powering the world's petroleum-based economy. Despite some formidable barriers, an oppositional network is developing that spans the 
North American continent. This paper discusses the diverse nature of this opposition through an examination of 26 collective activities involving some 243 organizations. The first part of the analysis discusses the internal characteristics and the network dynamics of these activities; this is followed by a spatial analysis of the relationships among the participant organizations. The final section of the paper suggests that an important mechanism for achieving collaborative integrity in the midst of what are oftentimes very challenging circumstances are carefully elaborated rhetorical frames designed to appeal to a diverse set of key stakeholders and policymakers.

INDEX

Keywords: oppositional networks, regionalism, rhetoric of opposition, tar sands

AUTHORS

JOSEPH JANOCHOSKI

University of St. Thomas 